\title{
Poemas de Renan Nuernberger
}

\section{Lição cabralina}

molhar uma esponja no discurso-rio retesá-lo não, sua sintaxe selvagem, absorvê-lo, pois, em seu ímpeto, em seu impacto com os poros puros, brio de assepsia. encharcar a esponja nas águas turvas do discurso-rio, sabê-la (a esponja) branca, mantê-la intacta equilibrando-se ao fazê-lo, inepto e rude, os cotovelos sujos na margem-barro. tornar as águas turvas, mago, água clara, não em poço - situação dicionária - mas em inodoro vinho novo (singular e magno), a palavra, sem molhar a mão, luva de borracha.

a esponja cheia, o poema, molde de excelência e refrescância de palavras caras em consonância plena, o poema dose diária de bons modos - à antiga zona amorfa da esponja-carcaça, uma ordem, o poema, arredio ao óbvio mas óbvio - não esprema! pois, a esponjapoema, assonâncias e paranomásias (gota irmã ante prima gota), nada há contra o esvair-se natural da coisa-água e sua inerente não-forma, como evaporação, com sorte o que sobra sem sabão nem cloro são as marcas nos braços (se não lavados) da margem do discurso-rio. à correnteza tensa, o impossível: heráclito. 
114 Magma

\section{Lero-ogídia}

para Mariana Quadros

calipso, se eu soubesse

que os percalços do

caminho são chupões,

afagos, ninhos,

cafunés e aconchegos

encerrava-se a guerra

(desde antes, muito cedo)

e cedia-me alegre (adeus

penélope, adeus telêmaco)

aos caprichos mais

ardentes, todos soltos

pelos pêlos: cocaína,

sol, delícia. no entanto,

sei - pois saiba - que, se

eu estivesse triste em

ceder-me a seus caprichos,

de nada adiantaria:

gozaria mais, colapso. 
Nesta rua o que vejo

Nesta rua o que vejo são

homens, mãos de estranhos

gestos, sem manchas os

sapatos e o terno

(remetem-me àquilo

que penso, esses homens:

é deixá-los sozinhos

que as taras se enervam

e do cóccix a mostra

recriam o sexo, outros

bebem o defunto, ganham

o sorteio, outro cega,

outro caga, esses

gomos de gente seguem

como, se livres, fossem

inteiros) de linho tramado

a compor-se no corpo

como, se carapuça,

caminhassem juntos. 
116 Magma

"Xerox, tigre, terror."

1. Me segura qu'eu vou dar um break

(deformado de "Um minuto de comercial", Waly Salomão re-publicado em Gigolô de bibelôs)

o HSBC patrocina este MESMO POEMAS

abate-se, creio, cerca

de $5 \%$

de imposto

de renda

em enjambements mais

ou menos VÁLIDOS.

paralelismos

contam - principalmente

FÔNICOS - e o melhor dos

recursos, o mais usado,

a captação de outros apoios

I

PETRobras PETRarca,

/ não

prejudica as palavras

(fim e meio auto-

‘ctones, flor

is a flower is as fezes)

antes favorece

o contato

com o público:

pérolas

porcos

virato

vulgata

(disque P para PODRES PODERES

ou V para VELUDOSAS VOZES)

* vote também por SMS

da garganta

cinge (pra deleite

: docere et movere)

a mesma

qualidade

dos produtos NESTLÉ

que você já conhece 
participe desta

promoção e concorra

a um fim-de-semana

com a família toda

em WASTE LAND

e um novo RENAULT

VALÉRY zero $\mathrm{km}$

responda:

que rima toante daria ao verso

"QUEM SUBIU, NO NOVELO DO CHICLETS"?

antes

guarde duas embalagens quaisquer

de produtos NESTLÉ

e envie com sua rima

(apoio HSBC, MESMO POEMAS

e parceiros)

2. Sócio do sósia da cópia

(deformado de "ó, poeta", poema de Régis Bonvicino publicado em Más companhias)

fiz tão

pouco publiquei

tão menos

nem sei se

posso proclamar

-me poeta ${ }^{\mathrm{TM}}$

(i, too, dislike it:

enfim)

um poeta ${ }^{\mathrm{TM}}$

que mal escreve

bom prato

só pastiches

batatas

um poeta ${ }^{\mathrm{TM}}$

entregue às traças

(entrave manjado:

esquema)

chego à velhice

sem aprender 
118 Magma

nada, viro

um purgante

insuportável

(minha meta:

mas nem isso)

e agora, nas costas

do rascunho

de mim

recebo massagens

confortos e manhas

(poesia®:

área de segurança)

3. Poema retirado de uma resenha de jornal

(deformado de "De uma crítica publicada num suplemento cultural de domingo", poema de Paulo Ferraz publicado em Evidências pedestres)

para Ana Rüsche

Os trinta e nove

poemas que constituem

o compêndio

consagram com mérito

o autor

por motivos óbvios: a

sintaxe inventiva, os

temas tratados com

incisiva perspicácia, o

estilo, peneirado

através das décadas

na melhor tradição

brasileira, conciso.

Os poemas, embora

únicos, possuem

todos uma mesma

tônica

algo inconfundível

que, junto com as 


\section{características}

acima expostas,

permitem

sem mais delongas

liquidar a falsa

discrepância entre

sua obra e a dos grandes

mestres

do século vinte.

Recomendo. 